THURSDAY, MARCH Io, I88I

\section{SIR WILLIAM HERSCHEL}

I.

$\mathrm{O}^{\mathrm{N}}$

N March I3, I78I, the planet Uranus was discovered by William Herschel, and very opportunely at this centenary of that memorable addition to the planetary system, Prof. Holden has presented us with a popular biography of the great astronomer and an outline of his works, which he has been careful to make intelligible to the general reader. ${ }^{1}$

Of the great modern philosophers, writes Prof. Holden, that one of whom least is known, is William Herschel, and we may appropriate the words which escaped him as one of the starless spaces in the constellation Scorpio passed through the field of his telescope, when his sister Caroline Herschel, his constant attendant during his night-watches, tells us he exclaimed, "Hier ist wahr haftig ein Loch im Himmel." A life of Herschel which shall be satisfactory in every particular, Prof. Holden remarks, can only be written after a full examination of the materials which may have been preserved by the family; but as two generations have passed since his death, he thinks no apology will be needed for a conscientious attempt to make the best use of material already in hand, scanty as it may be.

Herschel did prepare, about the year 1818 , a biographical note or memorandum, which was then placed amongst his papers, and which has not been made public, and his sister, writing in June, 1842 , mentions having commenced a work which she almost despaired of finishing, "The History of the Herschels," in which presumably her brother's life and work would have formed the main feature, but we do nat hear that in her then infirm state of health any considerable progress was made with it.

The only authentic sources of biographical information before the world are in the "Memoir and Correspondence of Caroline Herschel," published in 1876 , and in a much less known sketch of his life furnished by Herschel himself in a communication to Lichtenberg, dated November I5, 1783, and printed in the Göttingen Magazine of Science and Literature, iii. 4 ; this sketch was forwarded at the request of Lichtenberg, when acknowledging the receipt of memoirs on double stars, \&c., which Herschel had sent him.

William Herschel was born in Hanover on November 15, 1738, and was the second son of Isaac and Anna Herschel. The musical taste which he exhibited early in life appears to have been inherited from his father, who formed one of the band of the Hanoverian Guards in 1731. The eldest son Jacob was a clever musician, and first violin in the Court orchestra in I759; he afterwards joined his brother William in this country, and on returning to Hanover carried on a correspondence with him on musical subjects till his death in 1792 . The youngest brother Dietrich also shared in the musical abilities of the family, and at fifteen years of age was so far advanced as to be admitted into the Court orchestra. Towards the end of 1755 , when the Hanoverian Guards were ordered r "Sir William Herschel, his Life and Works." By Edward S. Holden, U.S. Naval Observatory, Washington. (New York: Charles Scribner's Sons, 188x.)

VoL. XxIII.-No. 593 to England, Herschel accompanied them as one of the band, and remained in this country about a year, when he returned to Hanover. During part of the disastrous campaign of 1757 he was on active service with the regiment, but after the defeat at Hastenbeck in July, it became evident that he had not the physical strength for the service, and his parents resolved to remove him. In connection with this circumstance Prof. Holden recalls a statement made by Sir George Airy, that the "removal" was a desertion, as he was told by the Duke of Sussex that on Herschel's first visit to the king after the discovery of the Georgium Sidus, "his pardon was handed to him by the king himself, written out in due form."

Herschel returned to England, though at what time does not appear. In fact from 1757 to 1760 we know nothing of his life. It is related in the Memoirs of Caroline Herschel that several pages referring to this period had been torn out in both her original Recollections and in the unfinished Memoir commenced in 1840 . In 1760 , however, he is again heard of, at Pontefract, as a young German in the band of the Durham militia, who spoke English almost as well as a native, and who was an excellent performer on the violin. It is conjectured that till his appointment as organist at Halifax in 1765 , pupils and public concerts must have filled up his time; during a portion of this interval of five years he resided at Leeds, and in April, 1764 , we are told he returned to Hanover on a very brief visit. In 1766 he obtained an engagement at Bath, and soon after was appointed organist at the Octagon Chapel. In this year, says Prof. Holden, he began a life of unceasing activity. His engaging manners made him friends, while " his talents brought him admirers and pupils, and pupils brought him money"; at this time he was giving thirty-five or more musical lessons in a week. In August, 1772, he proceeded to Hanover to take back to England his sister Caroline, afterwards his untiring assistant and companion in his surveys of the heavens. At this time his residence was in New King Street, Bath, and here in 1774 he had made himself a Gregorian telescope, probably on the model of Short's. In the preceding year, it is related of him, that he used to retire to bed with Smith's Harmonics and Optics, Ferguson's Astronomy, \&c., and his first thoughts on rising were how to obtain instruments for viewing the objects of which he had been reading. We are told no optician had settled in Bath at that time.

Prof. Holden mentions that in Journal No. I, preserved at the Royal Society, is a copy of Herschel's first observation of the nebula of Orion, made with his $5 \frac{1}{2}$-feet Gregorian reflector on March 4, 1774. In 1775, with a Newtonian telescope of $4 \frac{1}{2}$ inches aperture, and power of 222, also made by himself, he made his first review of the heavens, consisting in the examination of every star of first to fourth magnitudes and the planets; no records of these observations are now known to be in existence. In the same year the first 7 -feet reflector was finished, and in 1777 one of ro feet and one of 20 feet had been projected, and a grass-plot behind a house near Walcot turnpike, to which Herschel had removed at midsummer, I774, was prepared for its reception: this house offered more room for workshops, and the roof was available for observations. Of his early attempts at the construction of telescopes he wrote to Lichtenstein: "When, in the $\mathrm{U}$ 
course of time, I took up astronomy, I determined to accept nothing on faith, but to see with my own eyes everything which others had seen before me. Having already some knowledge of the science of optics, I resolved to manufacture my own telescopes, and after many continuous, determined trials, I finally succeeded in completing a so-called Newtonian instrument, seven feet in length. From this I advanced to one of ten feet, and at last to one of twenty, for I had fully made up my mind to carry on the improvement of my telescopes as far as it could possibly be done." A very good twentyfeet reflector was finished in 1783 , but the celebrated forty-feet instrument was not commenced until I785. Herschel tells us in his description of the latter telescope that in all he made "not less than 2007 -feet, 150 ro-feet, and about 80 20-feet mirrors, not to mention those of the Gregorian form, or of the construction of Dr. Smith's reflecting microscope," of which he also made a great number.

In or about 1779 Herschel removed to 19, New King Street, which was his last change of residence at Bath, and it was at this house that the planet Uranus was discovered. His first astronomical paper, on the variable star Mira Ceti, was written from thence, and appeared in the Philosophical Transactions for 1780: he had previously contributed a paper (his first publication) to the Ladies' Diary in 1779 , in answer to a prize question proposed by Landen, viz. " the length, tension, and weight of a musical string being given, it is required to find how many vibrations it will make in a given time, when a small given weight is fastened to its middle, and vibrates with it." In the same volume of the Phil. Trans. he published observations relating to the mountains in the moon; at this time and subsequently he measured the heights of about 100, on three different methods. Most of these measures were never printed, and as Prof. Holden remarks at this date they would probably be of no material service to science.

His next paper presented to the Royal Society on January $\mathrm{II}, \mathrm{r} 78 \mathrm{I}$, is entitled "Astronomical Observations on the rotation of the Planets round their Axes, made with a view to determine whether the Earth's Diurnal Motion is perfectly equable," a paper which Prof. Holden views as affording the first obvious proof of the truth of the statement made by Herschel thirty years later, when he said, "A knowledge of the construction of the heavens has always been the ultimate object of my observations." It marks too an advance in practical astronomy: not only are the results given, but careful estimates of the errors to which they may be liable is made, with a discussion of the source of such errors.

On March 13 foliowing Herschel made his great discovery of the planet Uranus, that Georgium-Sidus, as it was his wish it should be called, which made his name at once familiar throughout Europe. The discovery was announced in a paper communicated to the Royal Society on April 26 by Dr. Watson of Bath, an intimate friend of Herschel's, and strange as it may now appear to us, it is entitled "Account of a Comet." His own words referring to the circumstances of the discovery are as folJows :- " On Tuesday, the I3th of March, between ten and eleven in the evening, while I was examining the small stars in the neighbourhood of $\mathrm{H}$ Geminorum, I perceived one that appeared visibly larger than the rest: being struck with its uncommon magnitude, I compared it to $\mathrm{H}$ Geminorum and the small star in the quartile between Auriga and Gemini, and finding it so much larger than either of them, suspected it to be a comet. I was then engaged in a series of observations on the parallax of the fixed stars, . . . . and those observations requiring very high powers, I had ready at hand several magnifiers of $227,460,932,1536,2010$, \&c., all of which I have successfully used upon that occasion. The power I had on when I first saw the comet was 227. From experience I knew that the diameters of the fixed stars are not proportionally magnified with higher powers as the planets are; therefore I now put on the powers of 460 and 932, and found the diameter of the comet increased in proportion to the power, as it ought to be, on a supposition of its not being a fixed star, while the diameters of the stars to which I compared it were not increased in the same ratio. Moreover, the comet being magnified much beyond what its light would admit of, appeared hazy and illdefined with these great powers, while the stars preserved that lustre and distinctness which from many thousand observations I knew they would retain." The observations given in this paper extend to April I9, and Herschel adds he was "happy to surrender it to the care of the Astronomer-Royal" (Dr. Maskelyne) and others as soon as he found they had begun their observations upon it: so little idea had he six weeks after he first glimpsed the object of the great discovery he had made.

It is certain that at the date of this discovery the name of Herschel was unknown to the principal astronomers on the Continent, and it is almost ludicrous to read of the various guesses that were made respecting it. Prof. Holden transcribes the amusing passage from Bode's account of the discovery of Uranus: "In the Gazette Litteraire of June, $178 \mathrm{I}$, this worthy man is called Mersthel ; in Julius' Fournal Encyclopédique, HerTSCHEL; in a letter from Mr. Maskelyne to M. Messier, HERTHEL ; in another letter of Maskelyne's to Herr Mayer at Manheim, Herrschell [doubtless mis-readings]; M. Darquier calls him HERMSTEL. What may his name be? He must have been born a German." In the first notice of the discovery in the Connaissance des Temps he is called HOROCHELLE.

The telescope which Herschel was using on the evening of March I3, I78I, was that with which his second review of the heavens was made, a reflector ${ }^{1}$ of $85^{\circ} 2$ inches focus, 6.2 inches aperture, and power, 227. This survey, he writes in 1783 , "extended to all the stars of Harris's maps and the telescopic ones near them, as far as the eighth magnitude. The catalogue of double-stars and the discovery of the Georgium Sidus were the results of that review."

Arago says if Herschel had directed his telescope towards the constellation Gemini eleven days earlier (March 2 instead of March 13 ) the proper motion of the planet would have escaped him, for the planet was on the and near one of its stationary points, and adds, "On voit par cette remarque à quoi peuvent tener les plus grandes découvertes astronomiques." This implies a total misconception of the case : as Prof. Holden remarks :- "The

${ }^{1}$ When Sir John Herschel contemplated presenting one of his father's 7 -feet telescopes to the Royal Astronomical Society, Caroline Herschel wrote: "Its only being painted deal was because it should look like the one with which the Georgium Sidus was discovered." 
new planet was detected by its appearance and not by its motion." Herschel, referring to his discovery in his communication to Lichtenberg, says: "This was by no means the result of chance, but a simple consequence of the position of the planet on that particular evening, since it occupied precisely that spot in the heavens which came in the order of the minute observations that I had previously mapped out for myself. Had I not seen it just when I did I must inevitably have come upon it soon after, since my telescope was so perfect that I was able to distinguish it from a fixed star in the first minute of observation." It is not to be supposed that so striking an object would have been viewed once and forgotten, even if no motion were immediately detected.

As is well known, Herschel feeling deeply his indebtedness to the liberality of George the Third, desired to testify his gratitude by giving his planet a name which would mark the epoch of its discovery, and in his letter on the subject addressed to Sir Joseph Banks, then president of the Royal Society, writes, "I cannot but wish to take this opportunity of expressing my sense of gratitude by giving the name Georgium Sidus,

\section{-_- jam nunc assuesce vocari,}

$$
\text { Georgium Sidus }
$$

to a star, which (with respect to us) first began to shine under his auspicious reign."

Prof. Holden dwells upon the changes which may be considered to have been effected in the state of astronomy not only in England but in the whole world, simply by the discovery of Uranus. "Herschel's researches would have gone into the Philosophical Transactions as the work of an amateur astronomer, Mr. Herschel, of Bath. They would have been praised and they would have been doubted. It would have taken a whole generation to have appreciated them. They would have been severely tried, entirely on their merits, and finally they would have stood where they stand to-day-unrivalled. But through what increased labours these successes would have been gained ! . . Certainly, if Herschel's mind had been other than it was, the discovery of Uranus, which brought him honours from every scientific society in the world, and which gave him authority, might have had a hurtful effect. But as he was, there was nothing which could have aided his career more than this startling discovery. It was needed for him. It completed the solar system far more by affording a free play to a profoundly philosophical mind, than by occupying the vacant spaces beyond Saturn. His opportunities would have been profoundly modified, though his personal worth would have been the same." We think there are few astronomers who will not be able to follow Prof. Holden in the views he has thus forcibly expressed.

At the hands of Sir Joseph Banks, Herschel received the Copley Medal of the Royal Society in $178 \mathrm{r}$, for his "discovery of a new and singular star," and was formally admitted a Fellow of the Society on May 30, 1782. It was during this visit to London that Herschel was received by the king, and as he wrote to his sister the same day, met with a very gracious reception. Prof. Holden reproduces from the Memoirs of Caroline Herschel his letter of July 3, in which he describes his visit to the Court with a 7 -feet reflector, and the evening having been very fine, how the instrument had given general satisfaction; the king in particular, he states, " enjoys observations with telescopes exceedingly." Herschel returned to Bath in the last week of July, and immediately prepared for removing to Datchet.

Here, at the end of bis second chapter, we close our present notice of Prof. Holden's welcome volume, reserving for another week his third chapter on "Life at Datchet, Clay Hall, and Slough," and the concluding one on the general scientific labours of Herschel. It should be stated that while taking Prof. Holden's work as our text, particulars have been included in this notice which are not specially referred to in it, in view of the interest attaching to them at the present time, when, as stated above, a hundred years have elapsed since Herschel's discovery of Uranus doubled the known extent of the planetary system.

J. R. HIND

\section{EXTINCT BRITISH ANIMALS}

British Animals Extinct within Historic Times; with some Account of British Wild White Cattle. By J. E. Harting, F.L.S. (London: Trübner, 1880.)

THE wild animals formerly inhabiting Britain, which disappeared before the advance of the hunter and farmer in historic times, have hitherto only been treated in a disconnected fashion; in essays scattered through various periodicals, or in portions of books relating to other subjects. Mr. Harting has collected together in the present volume his own essays in the Field and in the Popular Science Review, and has brought to bear upon his subject a knowledge of records, and an acquaintance with sport, which render his work extremely valuable. His references are accurate, and he has availed himself of nearly every source of information. Consequently we have before us a work dealing with the bear, wolf, beaver, reindeer, and "wild cattle," worthy to be classed between Bell's "British Quadrupeds" on the one hand, and White's "History of Selborne" on the other, relating not merely to the animals, but to the forests in which they lived and to the mode in which they were hunted.

The common brown bear made its appearance on the Continent in the Pleistocene age, and crossed over to Britain while the areas of the North Sea and of the English Channel were fertile valleys abounding in animal life. Its remains occur both in the river-deposits and in the caves, and have been met with in the turbaries and alluvia of England and of Scotland, which belong to the prehistoric period. It was hunted by the Neolithic inhabitants of Britain, and used for food by the inhabitants of Colchester and Richmond in Roman times. From the "Penitentiale" of Archbishop Egbert (A.D. 750), in which the flesh of any animal torn by dog, wolf, fox, or bear, or any other wild animal is forbidden to be used for human food, it is clear that it was alive in this country at that time. In the days of Edward the Confessor Norwich furnished annually one bear to the king and six dogs for the baiting of it. This however does not prove the existence of wild bears in Britain at that date, because bear-baiting was almost a national sport among the English until bears became too costly and the public taste too refined for such brutal exhibitions. Fitz-Stephen tells us, in the reign of Henry II., that the young Londoners amused themselves in the forenoon of every holiday in the winter 